\title{
BORAY JÓZSEF ÁLLATORVOS ÉLETÚTJA SALGÓTARJÁNTÓL AZ AUSZTRÁL PARAZITOLÓGIAI TÁRSASÁG ELNÖKI POSZTJÁIG ${ }^{1}$
}

\section{THE LIFE OF VETERINARIAN JOSEPH BORAY FROM SALGÓTARJÁN TO THE PRESIDENCY OF THE AUSTRALIAN SOCIETY FOR PARASITOLOGY}

\author{
Kassai Tibor \\ az állatorvos-tudomány doktora, professor emeritus, Állatorvostudományi Egyetem \\ tkassai@t-online.hu
}

ÖSSZEFOGLALÁS

Boray József Budapesten szerzett állatorvosdoktori oklevelet 1950-ben. Parazitológiai témakörben itt szerezte meg 1954-ben az állatorvos-tudomány kandidátusa fokozatot. 1956-ban családjával Ausztráliába távozott. A Commonwealth Scientific and Industrial Research Organisation (CSIRO) Állategészségügyi Részlege Sydney-ben lévő McMaster Laboratóriumában, majd a Ciba-Geigy Mezőgazdasági Részlegének Kemps Creek-i Kutató Központjában kutatóként és kutatásszervezőként folytatott kiterjedt munkásságával a mételyek okozta bántalmak (trematodosisok), elsősorban a kérődzők májmételykórja nemzetközileg elismert szakértőjévé vált. Munkásságával kiérdemelte, hogy 1977-ben megválasszák az Australian Society for Parasitology, 1991-ben pedig az International Society of Medical and Applied Malacology elnökévé.

\section{ABSTRACT}

Joseph Boray studied veterinary medicine at the Veterinary College of Budapest, graduating in 1950. He obtained his PhD degree in 1954. In 1956 he and his family departed for Australia. He was commissioned at the Commonwealth Scientific and Industrial Research Organisation (CSIRO) at the McMaster Animal Health Laboratory in Sydney, subsequently he joined the Agriculture Division of Ciba-Geigy and became the head of the Ciba-Geigy Research Centre in Kemps Creek. The results of his extensive research and organising performance rendered him to be an internationally highly recognised specialist of the diseases caused by flukes (trematodoses), and of the liver fluke disease of ruminants, in particular. His services were recognised by electing him to the presidency of the Australian Society for Parasitology in 1977, and of the International Society of Medical and Applied Malacology in 1991.

${ }^{1}$ Rendhagyó biológussorsok a 20. században. Az MTA Tudomány- és Technikatörténeti Bizottság előadóülésén, Budapesten, 2019. szeptember 13-án elhangzott előadás szerkesztett változata. 
Kulcsszavak: életrajz, parazitológia, mételybetegségek, trematodosisok, májmételykór, csiga köztigazdák, kemoterápia, triklabendazol

Keywords: biography, parasitology, diseases caused by flukes, trematodoses, liver fluke disease, snail intermediate hosts, chemotherapy, triclabendazole

Boray József története abban a tekintetben számít rendhagyó biológussorsnak, hogy ö állatorvosi alapképzettség birtokában vált egy alkalmazott biológiai tudományterület, a parazitológia elkötelezett, kiváló kutatójává.

Salgótarjáni, zsidó, polgári családba született 1926. július 31-én. Apja a Salgótarjáni Vasmü Részvénytársaság mérnöke volt. Középiskoláit Losoncon végezte. Nagyapja Fegyvernek határában fekvő százholdas birtokán való nyári, vakáció alatti tartózkodásai alatt alakult ki a háziállatok iránti érdeklődése, sőt már az állatorvosi hivatás iránti vonzódása is. 1950-ben szerzett állatorvosdoktori oklevelet Budapesten, a Magyar Agrártudományi Egyetem Állatorvos-tudományi Karán.

Mindig a klinikus állatorvosi munka érdekelte. Habitusának érdekes adaléka, hogy egyetemi tanulmányai során annyira nem kedvelte a parazitológiát, hogy csak harmadik nekifutásra sikerült letennie a parazitológia szigorlatot a szigorú Kotlán Sándor professzor úrnál. Amikor azonban az állatorvosdoktori oklevél birtokában lehetősége nyílt egy parazitológiai témakörben elvégzendő aspirantúrára Kotlán Sándor akadémikus vezetésével, vállalkozott erre a feladatra. Kisérletes vizsgálatok a háziállatok echinococcosisáról, különös tekintettel az ebek echinococcosisára címü értekezése alapján 1954-ben, huszonnyolc éves korában, a legelsők között szerezte meg Magyarországon az állatorvos-tudomány kandidátusa fokozatot. Az Állatorvostudományi Főiskola Parazitológiai és Állattani Tanszékének munkatársaként 1951-től egyetemi tanársegédi, 1954től pedig egyetemi adjunktusi beosztásban részt vett a parazitológia gyakorlati oktatásában. Innen származik kettőnk személyes ismeretsége is. Boray kolléga komolyzenét, kultúrát, társaságot kedvelő ember volt. Kialakított maga körül egy kollégákból, tanítványokból, barátokból álló kis csoportot, akik rendszeresen összejöttek Borayék Alkotmány utcai lakásában egy kis „,zenehallgatásra”. Én is tagja lettem ennek a baráti körnek. Amikor azután előttem is megnyílt a lehetőség, hogy a friss állatorvosdoktori diploma birtokában Kotlán professzor aspiránsa legyek, Boray kolléga kedves, biztató szavainak is volt némi szerepe abban, hogy éltem e lehetősséggel, és így közeli pályatársak lettünk. 1952 és 1956 között a parazitológiai tanszéken szobatársak is voltunk. A pályatársi kapcsolatokon túl ezek az ifjúkori emlékek alapozták meg életre szóló barátságunkat. 
Boray József tudományos munkásságának szakaszai:

1950-1956 Magyarország

Állatorvosdoktori oklevelet szerez Budapesten (1950)

Az Állatorvostudományi Főiskola Parazitológiai és Állattani Tanszékének munkatársa, Budapest

Az állatorvos-tudomány kandidátusa (1954)

1957-1969 Ausztrália

CSIRO McMaster Animal Health Laboratory, Sydney

1969 Németország

Humboldt-ösztöndíjjal a Hannoveri Állatorvos-tudományi Főiskola Parazitológiai Intézetében kutat

1970-1972 Svájc

A Zürichi Egyetemen habilitál (1970)

A Zürichi Egyetem Parazitológiai Intézetének munkatársaként oktatja a helmintológiát az állatorvosi és az orvosi fakultáson

1972-1982 Ausztrália

CIBA-GEIGY Research Centre, Kemps Creek

1983-1999 Ausztrália

NSW Department of Agriculture Veterinary Research Laboratories, Glenfield

Department of Parasitology Elizabeth Macarthur Agricultural Institute, Camden

1999

73 éves korától hivatalosan nyugdijas

A forradalom leverése után, 1956 végén, feleségével, Évával és Péter fiukkal elhagy ták Magyarországot. Erre a lépésre nem világnézeti megfontolások vezették, hanem a karrierépítés külföldön tágabbnak vélt lehetőségei. Egyik 1963. évi levelében így fogalmazott: „Jól ismerem a kormány álláspontját a »disszidáltakkal« kapcsolatban, akik közé tartozónak soha nem éreztem magam.” 
Ausztráliába érkezésének napja 1957. február 13. Kutatói állást kapott a Commonwealth Scientific and Industrial Research Organisation (CSIRO) Állategészségügyi Részlege Sydney-ben lévő McMaster Laboratóriumában, ahol két év után Principal Resesarch Scientist beosztásban egy öttagú kutatócsoport vezetője lett. Munkájuk középpontjában a kérődző háziállatok mételyek által okozott bántalmaival, föleg a májmételykórral kapcsolatos mélyreható laboratóriumi és terepvizsgálatok állottak. Tisztázták, hogy Ausztráliában a közönséges májmétely, a Fasciola hepatica biológiájában egyedül a Lymnaea tomentosa nevủ amfibiotikus csigafaj tölti be a köztigazda szerepet. Sok új adatot közöltek a juhok és szarvasmarhák májmételykórjának, a juhok heveny paramphistomosisának és lándzsásmétely-kórjának patológiájáról, kórélettanáról, immunológiájáról, járványtanáról és kemoterápiájáról. A McMaster Laboratóriumban eltöltött tizenkét év kutatómunkájának eredményei alapján Boray doktor a mételyek okozta betegségek (trematodosisok) egyik nemzetközi viszonylatban legismertebb és leggyakrabban hivatkozott szakértőjévé vált. Amikor 2009-ben megjelent az A History of Parasitology in Australia and Papua New Guinea címü könyv, ő írta meg ennek a History of the McMaster Laboratory címü fejezetét, ezzel is kifejezésre juttatva első ausztráliai munkahelye iránti háláját és tiszteletét.

Mételyek nincsenek csigák nélkül. A mételyek életciklusának egy szakasza ugyanis a köztigazda szerepet betöltő csigák szervezetében zajlik le. Csigákban alakulnak ki a mételyek fertőzőképes stádiumai, a cerkáriák. A közönséges májmétely, a Fasciola hepatica esetében ezek a csigákból való kirajzás után a legelő füvén metacerkáriává alakulnak, és a legelés során jutnak be a fogékony, végleges gazdák szervezetébe. Boray kolléga kidolgozta a csigák laboratóriumi viszonyok közti tenyésztésének és kísérleti fertőzések számára metacerkáriák tömeges elöállításának a módszerét. E sokrétủ munka során a csigáknak is valóságos szerelmese és a malakológiának is elismert szakértője lett. A csigák biológiájának alapos megismerésére és a regionális csapadékviszonyokra vonatkozó adatok ismeretére alapozott, és könnyen megérthetö programokat dolgozott ki Ausztráliában a juhok és szarvasmarhák májmételykórja elleni védekezésre. Módszere alkalmas volt a májmételykór aktuális kockázatának elörejelzésére és a stratégiai védekezés megszervezésére, amelyet a United Nations Development Programme Food and Agriculture Organization (UNDP FAO) a világ több mint negyven országában bevezetésre ajánlott. Malakológus körökben kivívott tekintélyének és népszerüségének rangos elismerése volt, hogy 1991-ben megválasztották az International Society of Medical and Applied Malacology elnökévé. 1993-ban az ő irányításával került sor e szervezet III. Nemzetközi Kongresszusának Sydney-ben való megszervezésére.

1969-ben négy évre családjával együtt visszatért Európába. Egy Humboldt-ösztöndíjjal a Hannoveri Állatorvosi Főiskolán folytatta a lymnaeida csigák biológiájával, valamint a $F$. hepatica és a $F$. gigantica metacerkáriák életképességével 
kapcsolatos kutatásait. A Zürichi Egyetemen habilitált, majd - mint egyetemi magántanár - a Zürichi Egyetem Parazitológiai Intézetének munkatársaként kutatómunkája mellett német nyelven oktatta a helmintológiát az egyetem állatorvosi és orvosi fakultásain.

1972-ben visszatért Ausztráliába. A Ciba-Geigy Kemps Creek-i Kutatóközpontjának munkatársa és tudományos igazgatója lett. Feladata egy negyvenöt fös csoport munkájának irányítása. Sokat dolgozott és eredményesen. Az itt eltöltött tíz év volt a legproduktívabb szakasza kutatói pályafutásának. Legjelentősebb eredménye talán a triklabendazol különleges mételyellenes hatásának felfedezése volt. A triklabendazolt eredetileg ruhát védő rovarirtó szerként használták. Boraytól származott az ötlet, hogy ezt a szert a Ciba-Geigy-nél alkalmazott „Block Screening" módszerrel vizsgálják meg a májmételyek elleni hatékonyságra is. Kiderült, hogy ez az anyag már az egészen fiatal mételyeket is elpusztítja, szemben a többi mételyellenes szerrel, amelyek csak a májmétely kifejlett alakjaival szemben hatásosak, amikor a mételyek a májban már kifejtették káros hatásukat.

Minden alkotás első lépése az álmodozás valamely elérendő célról. Selye János is jó okkal választotta kiváló könyve címének azt, hogy az Álomtól a felfedezésig. Boray kolléga így írt 1981-ben az egyik levelében: „Erről álmodtam mindig, és ezért érdemes volt 8 évvel ezelőtt a Ciba-Geigy-hez mennem. Túl hosszú lenne leírni a történetét, de annyit mondhatok, nagy megelégedés számomra, hogy nélkülem nem született volna meg", ti. a triklabendazol mint a májmételykór máig leghatásosabb gyógyszere. Emellett több más gyógyszert is kifejlesztettek, köztük amidinszármazékokat a gyógyszerrezisztens kullancsokkal fertőzött szarvasmarhák kezelésére, a ciromazint a juh Lucilia cuprina okozta, Ausztráliában nagy veszteségeket okozó légynyüvességének, a nitroszkanátot a kutyák bélférgességének az orvoslására stb. A gabonafélék és a háztartások ízeltlábú kártevői ellen ható számos piacképes inszekticid készítményt is kifejlesztettek.

A Magyar Parazitológusok Társasága (MPT) 1981-ben nagy feladatra vállalkozott: házigazdája volt Budapesten az Állatorvos Parazitológusok Világszövetsége (World Association for the Advancement of Veterinary Parasitology, WAAVP) 9. Nemzetközi Konferenciájának. Erre az alkalomra Boray kolléga is hazalátogatott, és előadást is tartott.

1983-tól az Új-Dél-Wales Állam Mezőgazdasági Minisztériuma glenfieldi Állategészségügyi Kutató Laboratóriumának, majd a camdeni Elizabeth Macarthur Agricultural Institute parazitológiai részlegének vezetőjeként folytatta kutatásait. Ö ismerte fel először olyan májmétely törzsek megjelenését Ausztráliában, amelyek rezisztenssé váltak a triklabendazol hatásával szemben is. Ezt követően kutatásai kiterjedtek az ezek ellen is hatásos szinergetikus gyógyszerkombinációk vizsgálatára.

Közben jelentős változások történtek Boray kolléga magánéletében is. Elvált magyar feleségétől, de a kapcsolat ezután sem szakad meg közöttük. Hatvankét 
éves, amikor 1988-ban házasságot köt egy Joanna nevü ausztrál asszonnyal, akiben megértő és segítő, igazi társra talált.

Hivatalos nyugdíjazására hetvenhárom éves korában, 1999 végén került sor. Ekkor elnyerte Új-Dél-Wales Állam mezőgazdasági miniszterének „Meritorious Service Award” nevü kitüntetését.

A nyugdíjazás számára távolról sem jelentett nyugállományba vonulást. Mint magánvállalkozó (Fairhurst Parasitology Laboratory) még sok éven át tanácsadóként az érdeklődők rendelkezésére állt, és folytatta a metacerkáriák tenyésztését saját otthonában. Egy két évvel későbbi, 2001-ben kelt levelében így írt: „Ez évben leszek (ha leszek) 75

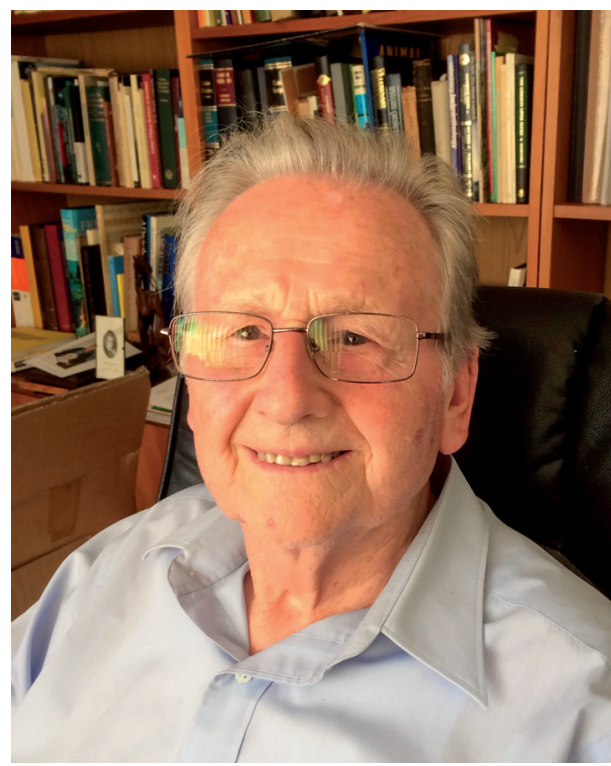

Boray József a nyolcvanas éveiben (szerzője ismeretlen) éves, és amikor ez a nap eljön, talán kezdek gondolkodni azon, hogy visszavonuljak a parazitológiai kísérletes munkától, ami nekem egyértékủ az életemmel." Öt évvel később, a 80. születésnapján bejelentette, hogy visszavonul a parazitológiától, de hozzátette, hogy „kivéve a csigákat".

2018. július 8-án, kilencvenegy éves korában Sydney-ben bekövetkezett halálával a nemzetközi parazitológus közösség elveszített egy kiváló tudóst és egy nagyszerü kollégát.

Több mint hatvanéves kutatómunkája során mintegy 130 cikket, monográfiát, könyvfejezetet publikált. Ezekben óriási tudásanyaggal gazdagította az állatorvosi parazitológiát, elsősorban a mételybetegségek járványtanát és az ellenük való védekezést, a mételyeknek az emlős és humán gazdáikkal és a köztigazdáikkal való kapcsolatát, a mételyek, galandférgek, fonálférgek, ízeltlábú külső élősködők kemoterápiáját és kemoprofilaxisát, valamint az ezen élősködő csoportokban megjelent gyógyszerrezisztens törzsek kezelését. Fontos kiemelni, hogy kutatásai mindig a gyakorlatban hasznosítható célokra irányultak, a farmereket kívánta segíteni az állataik gazdaságilag jelentős betegségei elleni védekezésben.

„Amíg napi 16 órát szakmámmal tudok törődni, nem panaszkodhatom”, írta egyik 1980-as levelében, amikor ötvennégy éves volt. A túlhajtott munka azonban az ő esetében sem bizonyult helyes életstratégiának. Egyik fárasztó előadói körútjáról hazatérőben, a sydney-i repülőtéren összeesett, és csak a kórházban tért magához. Anginás panaszai enyhítésére hetvenéves korában koszorúérmü- 
tétet hajtottak végre rajta négy sönt beépítésével. Hatvannyolc és hetvenkét éves korában egy-egy csípöízületi protézist kapott, nyolcvanhárom éves korában pedig az egyik térdízületét is protézisre kellett cserélni. Járóképessége meggyengült, de továbbra sem kímélte magát.

Boray József munkakedve és fáradhatatlan munkabírása hivatástudatából és szakterületének szenvedélyes szeretetéből táplálkozott. Mindenki életútjában és teljesítményében fontos szerepe van a személyiségnek. Érzelemvezérelt, magával ragadó, színes, derűs egyénisége alkalmas volt nyílt, baráti, előrevivő légkör megteremtésére a munkatársaival, a tanítványaival és általában az emberekkel való kapcsolatában. Szerette az embereket, és ő maga is szeretetre méltó ember volt. Egy plexivel bevont májmétely példány mindig nála volt, hogy bárkinek megmutathassa. Képes volt a maga tudományát megnyerő módon bármikor átadni hallgatóságának az egyetemi hallgatóktól a gyógyszerkutató vegyészeken és bürokratákon át a szkeptikus farmerekig. Humorra való készségére emlékeztet egy róla fennmaradt anekdota. Az egyik kongresszuson megkérdezték tőle, mi a titka a csigák sikeres tenyésztésének. Röviden így válaszolt: „You should love your snails.” Kedvelte a preklasszikus és a klasszikus zenét, az operákat, az irodalmat, szeretett kertészkedni is, kutyabarát volt. Kedvenc zeneszerzői müveinek hallgatásából is erőt tudott meríteni további munkájához.

A Magyar Parazitológusok Társasága 1987 áprilisában egy tudományos ülésen emlékezett meg mestere, Kotlán Sándor akadémikus születésének centenáriumáról. Ezen az emlékülésen részt vett Boray József is, akit ez alkalommal társaságunk tiszteletbeli tagjává választottunk. Boray kolléga 2001-től birtokosa volt az MPT emlékérmének is.

Számára mindig fontos maradt a szülőfölddel való kapcsolattartás. 1969 és 1983 között úgyszólván évente, és később is sürűn hazalátogatott. Figyelemmel kísérte az ország életének alakulását, kapcsolatot tartott magyarországi kollégáival, kísérleti és oktatási segédanyagok küldésével segítette munkájukat. 2000ben személyesen vette át a jubileumi aranydiplomáját az Állatorvostudományi Egyetem rektorától. Ekkor egy előadást is tartott 50 év a mételyek között címmel az MPT által a tiszteletére szervezett szakülésen. 2010-ben esedékessé vált számára a jubileumi gyémántdiploma átvétele a budapesti alma materben. Mindent elkövetett, hogy ezen az eseményen személyesen tudjon részt venni. Alapos kardiológiai kivizsgálás után azonban orvosai tanácsára kénytelen volt lemondani a hazautazás dédelgetett tervéről, hazalátogatásának utolsó lehetőségéről.

Boray kolléga az egyik alapító tagja volt az Ausztrál Parazitológiai Társaságnak. Munkásságának és személyiségének alighanem a legnagyobb elismerését jelentette, hogy ötvenhárom éves korában, huszonkét évvel az Ausztráliába való megérkezése után, 1979-ben e társaság elnökévé választották. Nagy megtiszteltetésként élte meg, amikor 1977-ben elnyerte a Fellow of the Australian College of Veterinary Scientists, 1988-ban pedig a Fellow of the Australian Society for Para- 
sitology minősítést. Nemzetközi elismertségének további jele volt, hogy 1998-ban az Állatorvos Parazitológusok Világszövetsége is tiszteletbeli tagjává választotta. Miután meghalt, a munkásságát méltató nekrológ jelent meg a Veterinary Parasitology címủ szaklapban.

\section{IRODALOM}

Beveridge, I. (ed.) (2009): A History of Parasitology in Australia and Papua New Guinea. Australian Society for Parasitology

Rolfe, P. - Eckert, J. - Love, S. et al. (2018): Obituary - Dr. Joseph Coloman Boray. Veterinary Parasitology, 261, 104-105. https://bit.ly/3fhJbw4

Selye J. (1967): Álomtól a felfedezésig. Budapest: Akadémiai Kiadó 